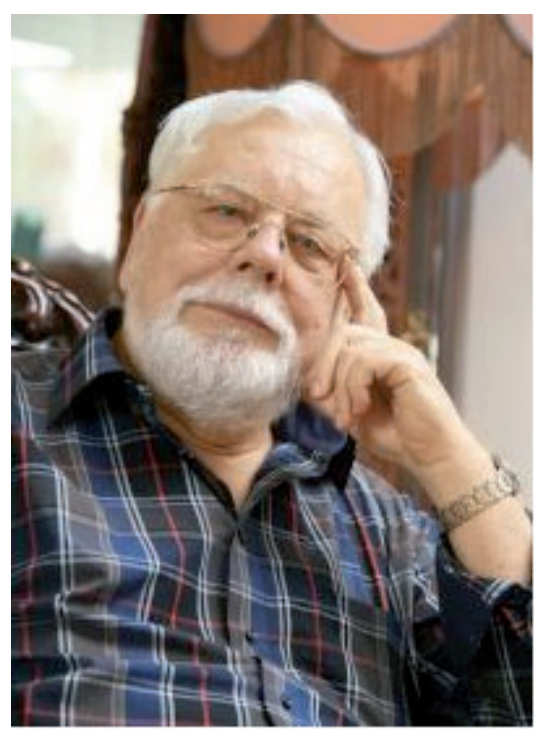

\title{
CHARACTERISTICS OF THE SCIENTIFIC AND IMPLEMENTATIONAL ACTIVITIES OF AVIATION PSYCHOLOGISTS AND SCIENTIFIC CONSULTANCY FROM THE PERSPETIVE OF THE 90 YEARS OF EXISTENCE OF THE MILITARY INSTITUTE OF AVIATION MEDICINE
}

Source of support: Own sources

Author's address: J. Terelak, Warsaw, Poland, e-mail: jan.terelak@onet.pl

\begin{abstract}
The author of this publication worked at Military Institute of Aviation Medicine (MIAM) in Warsaw in 1968-2018 with a small break. The paper is of a review nature and concerns the presentation of the scientific and implementational activities of Polish aviation psychologists from the perspective of the last half-century of the existence of the Military Institute of Aviation Medicine in Warsaw. The scientific activity includes, among others, empirical research on the assessment of mental and motor skills during tests in flight simulators: thermo- and diving chambers and centrifuges, while application research concerns mainly psychometric adaptation of psychological selection of candidates for military aviation and space flight and selection of military and civilian pilots. The organizational activity is related to the construction of tests and technical devices for group psychological research. The interdisciplinary nature of research is emphasized, thanks to cooperation of aviation psychologists with many specialists of aviation medicine and bioengineering.
\end{abstract}

Keywords: aviation psychology, flight simulators, space psychology, chronopsychology, polar psychology, psychological selection and pilot selection 


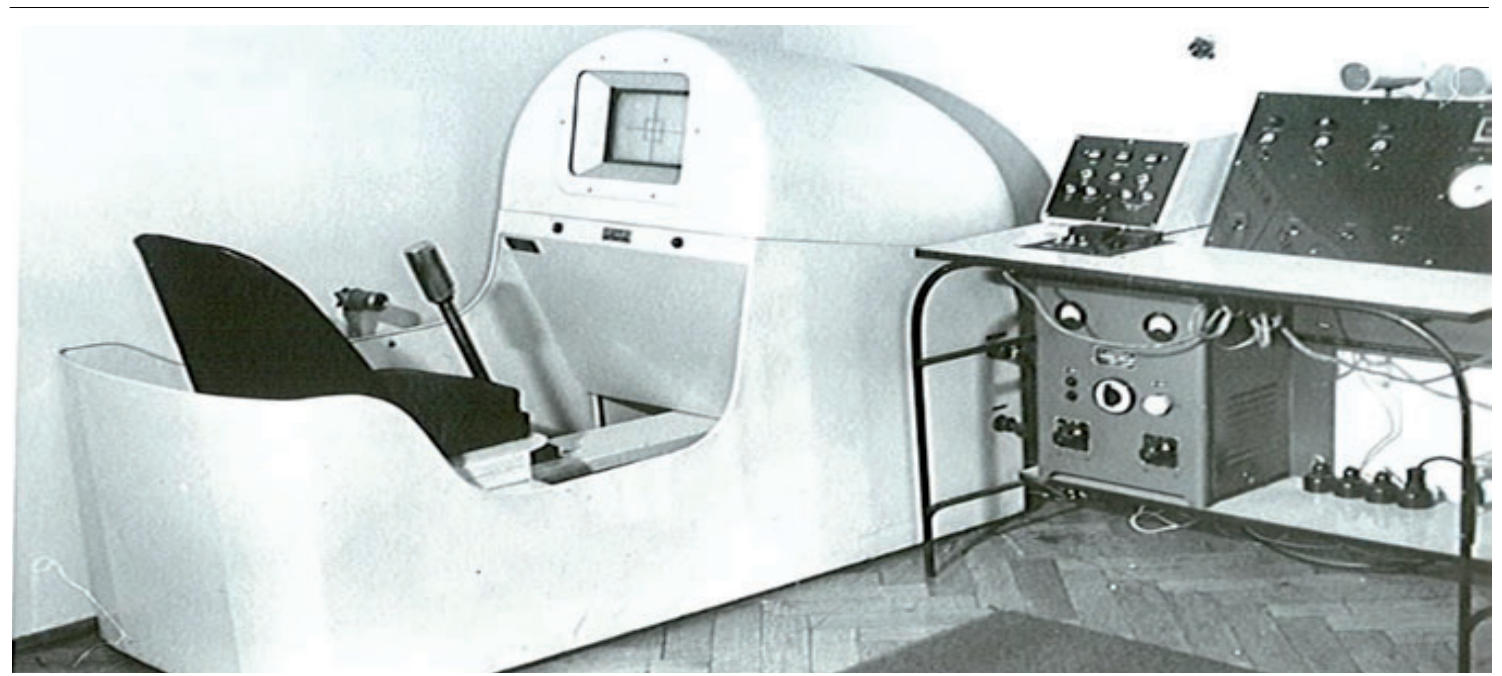

Fig. 1. One of the first SMA-3 British simulators in the 1970s to study attention and visual-motor coordination.

\section{INTERDISCIPLINARY NATURE OF RESEARCH OF POLISH AVIATION PSYCHOLOGISTS}

The wide range of scientific and implementational activities of aviation psychologists at MIAM was a result of its specificity resulting from the interdisciplinary nature and organizational autonomy. The psychologists working at MIAM had full organizational autonomy within the framework of the Psychometric Laboratory initially established at the Center for Aviation-Medical Research, and then at the Psychophysiology Department, which was transformed into the Aviation Psychology Department. Although the first head of the department was a physician mjr. Juliusz Gazda, MD his successors were psychologists. This, of course, did not prevent us from carrying out many interesting works of an interdisciplinary nature. Aviation psychologists have been cooperating to a significant extent with practically all theoretical clinics, facilities or labs. For example, psychological research carried out in cooperation with a psychoneurological clinic and an electroencephalography laboratory were unique not only in Polish psychology but also in the world. The substantive assistance of prof. Zbigniew Edelwein and prof. Jan Miszczak made it possible to use EEG records to calculate the socalled alpha index in a resting situation to diagnose pilots' temperament [30]. Other areas of cooperation with neurologists concerned among others: microwave effects on mental functions [10], effects of some neurological medicines on psychomotor performance and attention of a pilot [12]. On the other hand, the cooperation with the internist clinic concerned mainly the pathogenesis of psychosomatic disorders of pilots in relation to aviation stress [9], while the laryngological clinic was a substan- tive support for psychologists in posturographical examinations and the mechanism of spatial disorientation of pilots [18]. Interesting research was conducted in cooperation with a clinic and an ophthalmological laboratory on spatial vision and the oculomotor saccade mechanism of visual attention[17]. Psycho-pharmacological and psycho-toxicological research conducted in cooperation with specialist research laboratories of MIAM, led by prof. W. Święcicki and dr. Z. Koter, allowed to determine the influence of various types of drugs on the mental and motor fitness of a pilot [23]. Contacts with the Performance and Physical Education Department, led by dr. Henryk Sulajnis, and later by dr. Krzysztof Klukowski, in cooperation with assistant professor Zbigniew Sarol focused the psychological research on the evaluation of the effectiveness of pilots' rest in Military Training and Fitness Centers in Gronik and Mrągowo [25].

Attention should be drawn to psychological research conducted with the use of unique flight simulators: thermal chambers [24], diving chambers [15], centrifuges [2], catapults [1], aviation gymnastic equipment [22] and flight simulators [7].

Psychological tests were also carried out on dynamic simulators as well as in real flight conditions. It was possible because we had a psychologist in the team, lieutenant colonel dr. Henryk Świątek, who was a combat pilot and flight instructor in school regiments.

\section{INTRODUCTION OF NEW SCIENTIFIC DISCIPLINES IN POLISH APPLIED PSYCHOLOGY}

Space Psychology - as part of MIAM's research programme Polish Academy of Sciences (PAN) and INTERKOSMOS within the Department of Space 


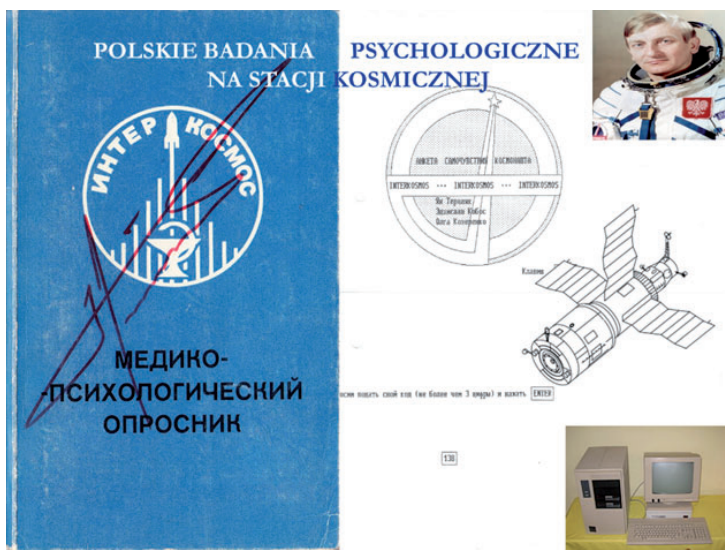

Rig. 2. The Original Space Questionnaire ("Oprosnik") signed bytheCosmonautMirosławHermaszewski, who filled it in on the flight on the ship"Sojuz".

Psychology led by dr. Romuald Błoszczyński and later dr. Jan Terelak, a new field of applied psychology, namely space psychology, was established. The issue of space psychology included, among others: selection of candidates for the first Polish astronaut, experiments on spacecraft (e.g. Relaxation), theoretical aspects of selection of crews of spacecraft, psychological effects of isolation, etc. These issues were studied in the years 1986-1991 within the framework of the Central Programme for Basic Research 01.20 entitled "Gwarancja niezawodności psychologicznej członków załogi w długotrwałych lotach kosmicznych" ("Assurance of psychological reliability of the crew members in long-term space flights") carried out under the intergovernmental INTERKOSMOS programme and coordinated Space Research Centre of the Polish Academy of Sciences. Scientific research conducted by Jan Terelak included two natural experiments, conducted in extreme conditions of space flight and the most unfriendly conditions on Earth for humans - Antarctic conditions. Research carried out at the space station (Orbital Assembly "Salut 6 - Soyuz 29 Vostok") under the cryptonym "Oprosnik" (Questionnaire) to assess the redistribution of working and resting time of cosmonauts on real flights and the behavioral effects of operation in changed photo-ecological conditions (biorhythms).

Polar psychology - connected with the second natural experiment conducted by dr. Jan Terelak during a one-year stay at the Antarctic Station of the Polish Academy of Sciences named after $\mathrm{H}$. Arctowski in Antarctica, on the

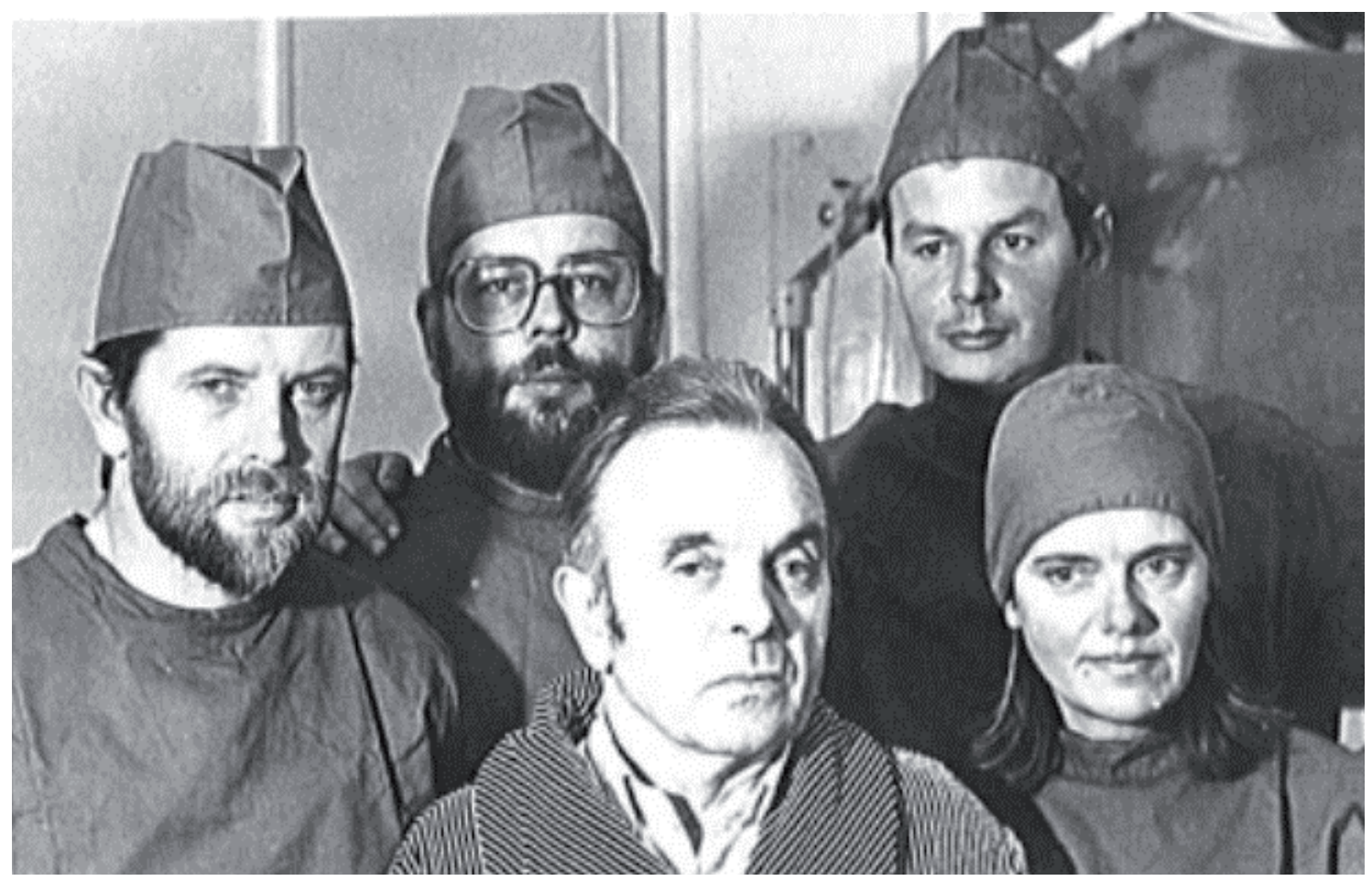

Fig. 3. Team performing the first historical appendectomy in the H. Antarctic Station of the Polish Academy of Science on the 22nd December 1978 (upper row, from the left: dr. Józef Domaszuk (surgeon from the Military Institute of Aviation Medicine), dr. Jan Terelak (psychologist from the Military Institute of Aviation Medicine, as "anesthesiologist"), dr. Maciej Rembiszewski (head of winter camp); lower row: Marian Bieńko (patient-fishermen from the m/t "Jowisz"), dr. Anna Jakubiec-Puka (biologist from the Polish Academy of Sciences, as "scrub nurse"). 
psychological effects of social isolation as the precursors of behavior in future long-term space expeditions. The description of the experiments and the results of the research are presented in two books $[46,47]$. The research is unique in the global literature on the subject, as only four psychologists in the twentieth century participated in such an experiment personally, and because the research was conducted every two weeks for a year, which allowed to determine the dynamics of changes in the behavior of many psychological parameters. Also unique was the experience of a polar psychologist, who in extreme circumstances was a member of a "unique" team, which performed four surgical operations, as illustrated in fig. 2. In addition, problems of adaptation to low temperatures [24] and the body's reaction to changed photoecological [5] conditions were the subject of research in extreme Antarctic conditions.

Chronopsychology - referring to a new chronobiological paradigm. Psychologists undertook interdisciplinary research in the years 1978-1990 carried out within the framework of the governmental programme R III-14 on "The influence of biological rhythms on human and animal organisms", concerning the moderating role of circadian rhythms on the daily mental and psychomotor performance of military pilots, as well as the evaluation of the effectiveness of multi-shift [4] work and the "jet pilot syndrome" in transcontinental flights in LOT Polish Airlines [32]. Work was also undertaken on the Polish version of the questionnaire method of examining morning vs. evening chronotypes [28].

\section{IMPROVING SCIENTIFIC QUALIFICATIONS}

During the discussed period, aviation psychologists obtained the following titles and scientific degrees: 15 persons obtained doctoral degrees (R. Błoszczyński, K. Galubińska, Z. Baranowski, H. Świątek, J. Maciejczyk, J. Terelak, L. Radomski, Z. Kobos, M. Wonicki, J. Turlejski, J. Szczechura, O. Truszczyński, T. Jasiński, A. Tarnowski, M. Macander). Out of this group, 5 persons (R. Błoszczyński, P. Pokinko, J. Terelak, A. Tarnowski, T. Jasiński) obtained the degree of PhD habilitatus, while 1 person obtained the title of a "presidential" professor (J. Terelak) and this is the only case in the entire history of the 20th century Polish military and aviation psychology.

\section{PARTICIPATION OF POLISH AVIATION PSYCHOLOGISTS IN ADAPTATION OF RESEARCH EQUIPMENT AND VALIDATION OF TESTS USEFUL FOR EXAMINATION OF FLYING PERSONNEL}

Access to many modern flight simulators, as well as the construction of our own research equipment in cooperation with MIAM engineers made that the research facilities of aviation psychologists had no equals compared to psychological laboratories at Polish universities. It has also often been an advantage of the willing cooperation with the Department of Aviation Psychology of many civil scientific institutions in Poland. An example is the development of the first concept and the implementation of "Apparatus for group psychological research controlled electronically" (Ministry of National Defence Award) and devices for automatic exposition of visual tests $[14,20]$, or Poland's first "Computercontrolled psychological laboratory" [38], or finally the "Computer System for Psychological Testing", called the "Warsaw Test System" [21]. It should also be added that the Department of Aviation Psychology was the first in Poland to use computer versions of the tests for the selection of pilots and subjected it to public assessment by the community of psychologist [39] and had the most modern set of laboratory equipment called the "Viennese Test System", including a library of several dozen psychological tests and coupled with external coordinators, which allowed for comprehensive research of cognitive processes (intelligence, memory, attention), personality as well as visual and motor coordination, and which at that time was the world standard in the best scientific institutions [53]. It should also be noted that the Department of Aviation Psychology had an apparatus, unique on a global scale, for examining visual attention processes at the level of saccade eye-movement (NAC-4 and NAC-5). The research conducted in the Department of Psychology with the use of an eye tracker was unique not only in Poland, both in the scope of basic research [16,19], but also applied ones, e.g. in solving ergonomic problems in designing a cabin of a prototype of a Polish helicopter based on the MI-2 structure [27].

\section{CONTACTS BETWEEN MIAM PSYCHOLOGISTS AND THE SCIENTIFIC WORLD OF PSYCHOLOGISTS}

One should also mention the cooperation of the Department of Psychophysiology and then Aviation Psychology with the majority 
of Polish universities (e.g. the University of Warsaw, Jagiellonian University, Catholic University of Lublin, University of Wrocław, Adam Mickiewicz University in Poznań, University of Gdańsk, University of Łódź) and foreign scientific and research facilities of similar interests (e.g. in Moscow, Prague, Dresden, Kecskemét, Bucharest) within the framework of the research programme of the Polish Academy of Sciences/ INTERKOSMOS led by MIAM. This cooperation was extended by the Western countries, when two years before Poland officially joined NATO in 1992, prof. Jan Terelak was invited to cooperate under the "NATO Psychologists Working Group", thanks to which for several years together with his younger colleagues, psychologists from WIML, they were able to participate annually in international scientific symposiums IAMPS (International Applied Military Psychology Symposium) or IMTA (The International Military Testing Association) and not only to present their own research results, but also to get acquainted with the equipment of research laboratories and methodology of selecting candidates for the army, including military aviation, in almost all modern armies of the world, including the American $[55,56]$ and Australian ones [54]. At the same time, WEAAP (Western European Association for Aviation Psychology) was contacted, which had to change its name to EAAP (European Association for Aviation Psychology) due to procedural reasons before accepting Polish aviation psychologists. Thanks to this, we participate in scientific conferences organized by this company in many European countries. The crowning achievement of this cooperation was entrusting the organization of an international symposium in 2002, which took place in Warsaw to Polish side (Department of Aviation Psychology MIAM and Chair of Occupational Psychology and Stress at Cardinal Stefan Wyszyński University in Warsaw)[50]. Following Poland's accession to NATO and the European Union, the community of Polish aviation psychologists accepted research standards [51,52], also having experience gained during peacekeeping missions [57].

\section{EXPERT, POPULARIZATION AND EDUCATIONAL ACTIVITY IN THE FIELD OF AVIATION PSYCHOLOGY}

The expert activity concerns the participation of psychologists as members of the Subcommittee Investigating Disasters and Accidents in both military and civil aviation and concerns, on the one hand, the participation in the investigation of a specific aviation event and, on the other hand, the development of research procedures and training of young students of aviation psychology [26]. Educational activity was connected both with lecturing in aviation psychology for doctors specializing in aviation medicine and writing scripts for them in the special periodical journal "Informacja Lotniczo-Lekarska WIML" [35] ("AeroMedical Information WIML"), writing popular science articles for aviation magazines, such as "Astronautyka" [42] ("Astronautics"), or "Przegląd Wojsk Lotniczych i Wojsk Obrony Powietrznej Kraju" [37] ("Review of the Air Forces and the Air Defense Forces of the Country") and "Informator Instytutu Technicznego Wojsk Lotniczych" [29] ("Informer of the Air Force Institute of Technology").

The scientific educational activity concerned writing scientific articles on aviation psychology in scientific specialist journals, e.g. "Medycyna Lotnicza" ("Aviation Medicine"), "Polski Przegląd Medycyny Lotniczej" ("Polish Journal of Aviation Medicine"), "Aviation, Space and Environmental Medicine" and "International Journal of Aviation Psychology". An important educational activity was writing popular-scientific [36] books and monographs as well as textbooks in the field of aviation psychology [41,43]. Documentation of bibliographies on the achievements of Polish aviation psychology was successively published in scientific psychological journals [8,31]. It is also worth noting that Jan Terelak translated a textbook from the Russian language (with a Polish preface), written by the classics of aviation and space psychology B.F. Lomov and K.K. Platonov in 1984 [6].

Finally, it is worth mentioning that military psychology, and within its framework aviation psychology, is the oldest discipline of applied psychology in Poland, with significant achievements both in Polish and global science, which is worth emphasizing on the occasion of such a beautiful 90th anniversary of the cradle of aviation medicine and psychology in Poland.

\section{RETINUE OF SCIENTIFIC CONSULTANTS IN THE FIELD OF PSYCHOLOGY}

It is worth to describe briefly the silhouettes of MIAM scientific consultants in the field of psychology, who over the years have been preparing the staff of specialists in a niche field which undoubtedly is aviation psychology. 
Bohdan Zawadzki (1902-1966). After repatriation from Ukraine to Poland, he graduated from the Zamoyski Junior High School in Warsaw in 1920, and then took up psychology studies at the University of Warsaw under the direction of prof. Władysław Witwicki. After completing studies as an assistant at the Department of Psychology under the direction of prof. Władysław Witwicki, he defended his doctoral dissertation in 1928 "O komizmie. Studium Psychologiczne." ("On comedy. Psychological study"). He combined the work of an assistant and later a lecturer (19301932) at the University with his practice at the Center for Aviation and Medical Research, where, together with mjr. dr. Włodzimierz Missiuro, created the Psychological and Physiological Laboratory. In the years 1929-1930, he complemented his psychological studies in Berlin, and in the years 1932-1933 in Vienna under the supervision of Karol and Charlotte Buhler. In the years 1933-1934, he continued his studies in the United States. After his return to Poland in the years 1935-1936, he took over the management of the Department of Psychology at the Stefan Batory University in Vilnius. After the liquidation of the University in Vilnius, in February 1940 he left again for the United States, where he taught at various universities (Smith College, Wellesley College, Sarah Lawrence College). In the years 1946-1966, he worked as a professor of psychology and psychopathology at the City College of New York. While staying in the USA, he maintained intensive contacts with Poland, repeatedly feeding psychological libraries in the country with scientific literature.

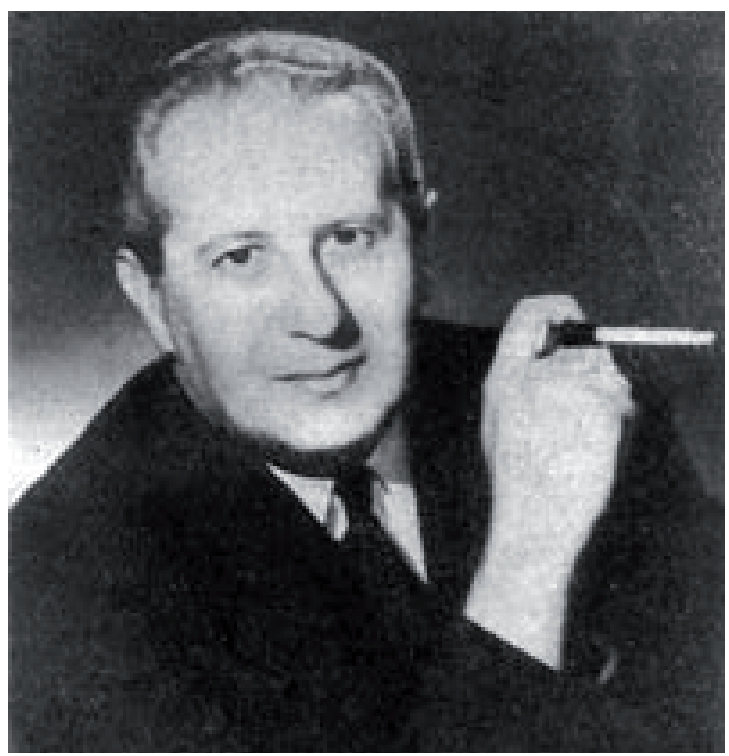

Fig. 4. Prof. Bohdan Zawadzki (1902-1966), http:// psych.uw.edu.pl/o-nas/historia/slawniprofesorowiezasluzeni-pracownicy/bohdanzawadzki/ (12.10.2017).
The sympathy of prof. Bohdan Zawadzki to Military Institute of Aviation Medicine in Warsaw was associated with a proposal to transfer a part of his scientific library in the field of psychology and psychiatry after the war, which was thwarted due to political reasons and eventually the library was taken over by the Psychometric Laboratory of the Polish Academy of Sciences'. Thanks to the courtesy of dr. Mieczysław Choynowski, we made use of this library in a protectionist manner, and especially of the 20 -volume series concerning psychological tests for the examination of mental and psychomotor skills, developed under the editorship of a world-renowned intellectual theoretician prof. J.P Guilford. As a result, most of the psychological tests used in Poland to examine aviation abilities are adaptations of the tests of American military aviation.

Włodzimierz Missiuro - graduated in medicine with the title of a doctor of all-medical sciences. He specialized in physiology. After Poland regained its independence, he was admitted to the Polish Army. He was promoted to the rank of a major physician with seniority on June 1, 1919. In the years 1923-1924, as an officer of the 7th Sanitary Battalion from Poznań with the rank of "additional officer", he was a physician at the Central Military School of Gymnastics and Sports. In 1928, he became a deputy head of the Centre for Aviation and Medical Research, and in 1932 he served at the Central Institute of Physical Education in Warsaw. He was later promoted to the rank of a lieutenant colonel, physician. From 1933 to 1938 he was a lecturer at the Physiology Laboratory of Education and Sport at the Department of Human Physiology of the Faculty of Medicine of the University of Warsaw. From 1931 to 1939, he was the head of the Physiology Department at the University of Physical Education in Warsaw. In 1937 he co-organized the Polish Society of Sports Medicine. He was a member of the Housing Cooperative Association of the Professors of the University of Warsaw [11].

After the outbreak of the Second World War, during after the Soviet aggression against Poland on September 17, 1939, a day later he was arrested by the Soviets. He was held in the prisoner-ofwar camp in Kozielsk from 1939 to 1939. Later, he stayed in the camp in Pawliszczew Bor. From June 24, 1940 to September 31, 1941, he was imprisoned in the NKVD prisoner-of-war camp in Gryazovets. Under the Sikorski-Majski Agreement of July

\footnotetext{
1 Currently, the library is located at the University of Warsaw in the Diagnostic Techniques Laboratory at the Faculty of Psychology of the University of Warsaw, named after prof. Bohdan Zawadzki.
} 
30, 1941, he regained his freedom and joined the Polish Army formed in the USSR led by gen. Władysław Anders. He was employed as a lecturer at the Department of Physiology at the Polish Faculty of Medicine in Edinburgh.

After the liberation, he returned for a short period of time to Łódź, where he took over the Chair of Occupational Medicine of the Faculty of Medicine at the local university, already as a full professor, and then moved to take the same position in Warsaw, at the same time taking over the management of the Department of Physiology at the University of Physical Education. He established the Scientific Institute for Physical Culture and the Scientific Committee for Physical Education. He managed the Chair of Human Physiology at the Medical Academy in Warsaw. Prof. Włodzimierz Missiuro carried out scientific consultations with Military Institute of Aviation Medicine aviation psychologists [13] on the psychological and physiological mechanisms of fatigue. He published scientific papers in the field of sports physiology, aviation and labor. From 1929 to 1932 he was the editor of the quarterly "Przegląd Sportowo-Lekarski" ("Sport and Medical Review") - a quarterly de-

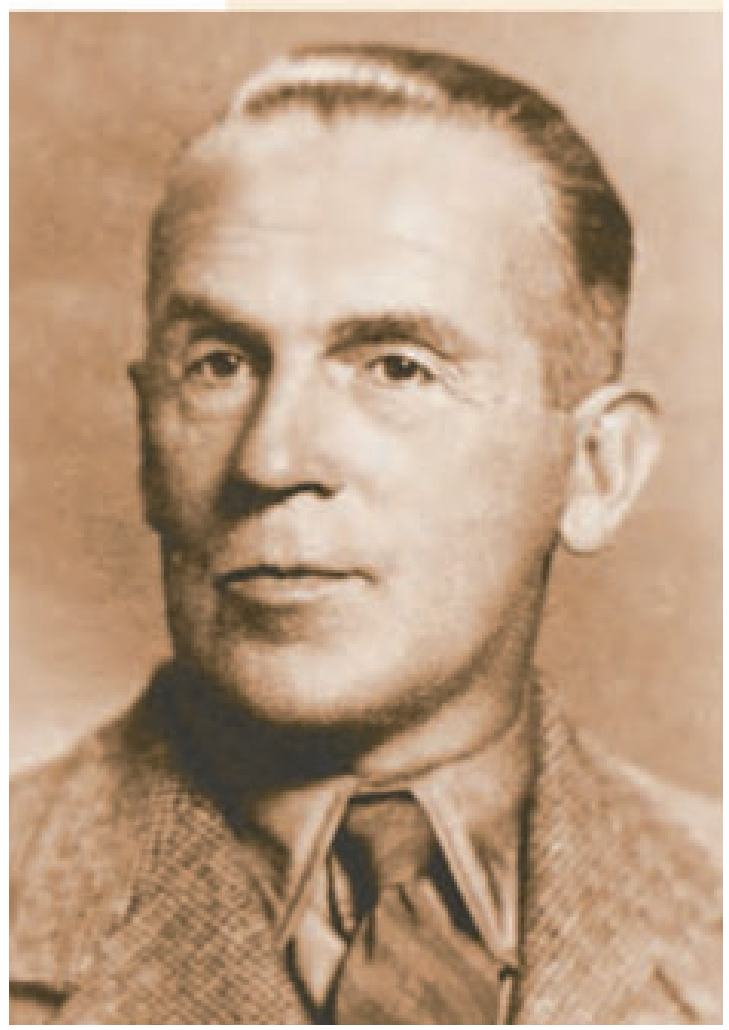

Fig. 5. Włodzimierz Missiuro (1892-1967), http:// www.wuw.pl/data/include/cms/monumentaebook/pdf/Portrety-Uczonych-ProfesorowieUW-po-1945-L-R.pdf (12.10.2017). voted to the physiology, pathology and hygiene of sport, physical education and work. One of his assistants was dr. Krystyna Nazar, later working at the Polish Academy of Sciences, and being a scientific consultant at MIAM.

Biegeleisen-Żelazowski Bronisław - psychologist, engineer. He was one of the pioneers of the occupational psychology in Poland. As a professor at Lviv Politechnic, and in the post-war period at Warsaw University of Technology, the University of Warsaw and the University of Łódź - he dealt with issues related to health technology, psychotechnical research, psychology of work and work organization. He was also the organizer and director of the first Polish Psychotechnical Institute in Kraków (1925) [3]. In 1949, he was appointed an independent research worker at the Institute of Economics and Organization of Industry in Warsaw, where he established the Labor Standardization Department. In the 1960s, he founded and became the head of the Psychology Department at the Motor Transport Research Centre in Warsaw. In 1964 he published "Zarys psychologii pracy" ("The outline of Work Psychology"), which was used by the first aviation psychologists for learning and he willingly consulted MIAM psychologists on this subject, as well as an engineer in the field of aviation technology.

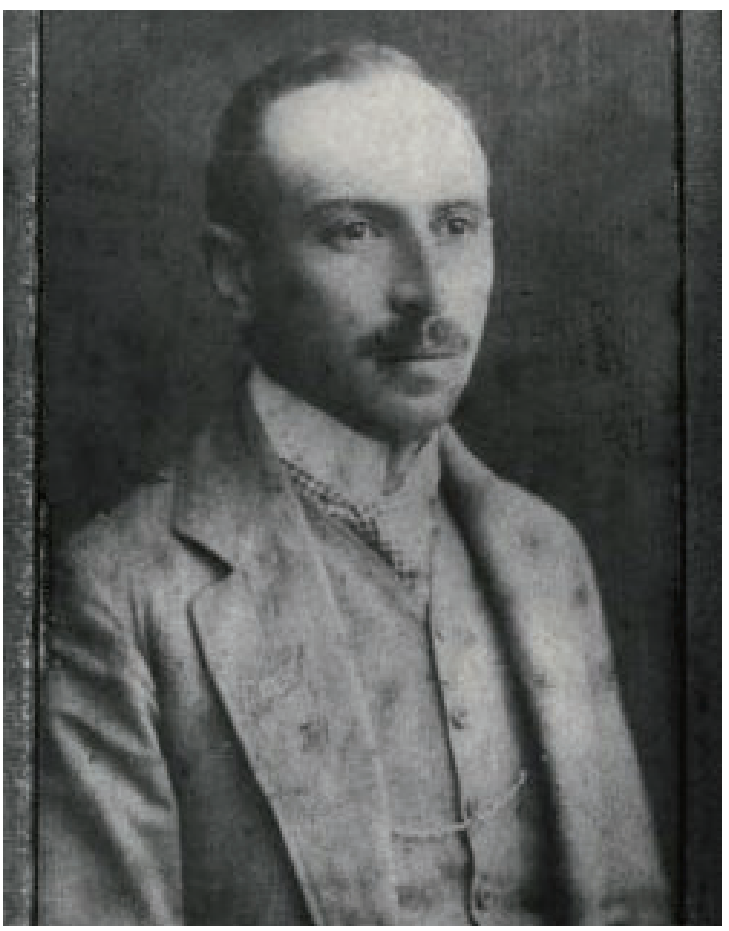

Fig. 6. 6. Prof. Bronisław Biegeleisen-Żelazowski (18811963), http://www.archiwum.wfis.uw.edu.pl/ bibfis/wp-content/uploads/archiwum-cyfrowe/ tablica-pamiatkowa-ku-czci-KazimierzaTwardowskiego/t40.html (12.10.2017). 
Mieczysław Kreutz - professor at the University of Warsaw and scientific supervisor of Military Institute of Aviation Medicine psychologists in the 1950s. Born in Lviv, where he graduated from a junior high school and from the Lviv University at the Faculty of Philosophy. He studied biology and philosophy under the supervision of Kazimierz Twardowski, among others. Since 1921 he has been an assistant at the Department of Psychology of the Jan Kazimierz University in Lviv. PhD degree in 1924, habilitation "Zmienność rezultatów testów" ("Variability of test results") in 1927. Since 1928 , a deputy professor and head of the Department of Psychology (after Twardowski). In 1934 he was appointed an associate professor. In 1946, he was appointed a full professor at the University of Wrocław, where he organized psychological studies and the Chair of Psychology. Since 1953 at the University of Warsaw, where he headed the Chair of Experimental Psychology until the mature exam. Consistent continuator of certain psychological issues of the Lviv-Warsaw school. An advocate of introspection and test methods that include a component of the tested person's consciousness. A critic of existing diagnostic tests. He is the author of the so-called maximum method, i.e. the method of measuring the abilities with the use of the maximum result. Works devoted to the

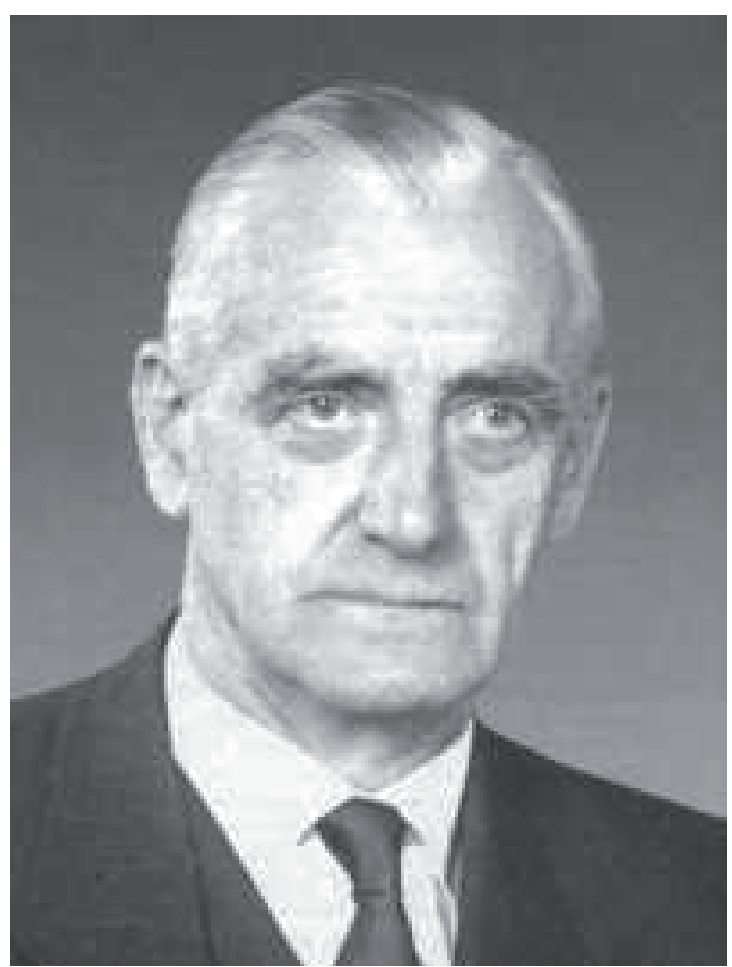

Fig. 7. Prof. Mieczysław Kreutz (1893-1971), http:// psych.uw.edu.pl/o-nas/historia/slawniprofesorowiezasluzeni-pracownicy/ mieczyslaw-kreutz/ (12.10.2017). issue of will (will understood as the process of inhibiting an impulse). During the Warsaw period, he was interested in the subject of understanding texts, and he developed a method for studying the subject of understanding texts. Primary works: "Zmienność rezultatów testów", cz. I-II ("Variability of test results", Lviv 1927, 1933), "Kształcenie charakteru" ("Character training", Warsaw 1946), "Podstawy psychologii" ("Basics of psychology", Warszawa 1949), "Rozumienie tekstów" ("Understanding texts", Warsaw 1968).

Janusz Reykowski - professor at the University of Warsaw and head of the Department of Psychophysiology at MIAM in the 1960s and 1970s. Until 1968 a consultant at the Military Institute of Aviation Medicine. From 1967 to 1968, he was also the head of the Feliks Dzierżyński Social Research Center at the Political-Military Academy. From 1980 to 2002 he was a director of the Institute of Psychology of the Polish Academy of Sciences. In 1996, he co-founded the University of Social Sciences and Humanities (SWPS). Since 1984 he has been an honorary member of the Polish Psychological Association, and since 1991 a member of Academia Europea. He has also worked, mainly as a consultant, in numerous foreign scientific institutions, such as: Center for Advance Studies in Behavioral Sciences, Stanford, California, (Fellow 1990-1991), International Society for Study of Behavioral Development: Member of the Executive Committee (1976-1985), European Association of Psychology of Personality: Member of the Executive Committee (1985-1990), International Society of Political Psychology: Member of the Governing Council (1991-1993), President (2004-2006), Altruistic Personality and Prosocial Behavior Institute - Humboldt State University:

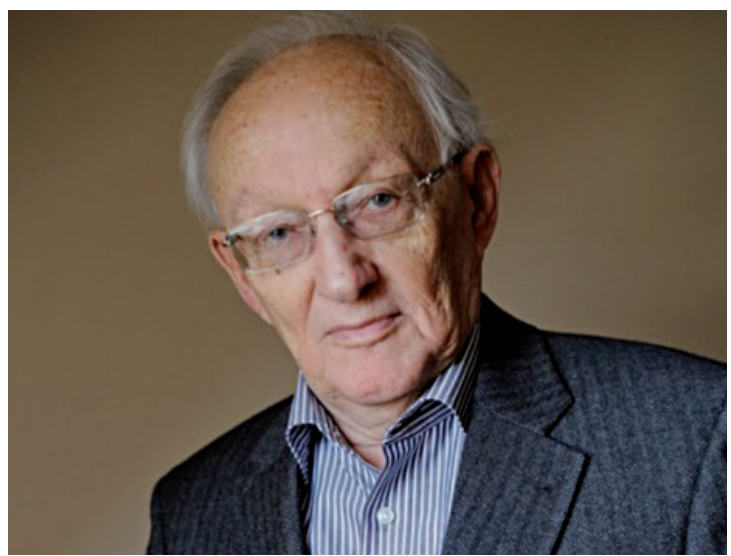

Fig. 8. Prof. Janusz Reykowski ( 1929-), http://psych. pan.pl/pl/pracownia-psychologii-politycznej/ janusz-reykowski/ (12.10.2017). 
Consultant (1983-), European Center for Research and Documentation in Social Sciences - Vienna Center: Member of the Board of Directors (19911993), De L'Academie Europeenne Des Science, Des Arts et Des Letters (Membre Titulaire 2001), Member of Graduate Program in Political Psychology School of Social Sciences, University of California, Irvine (2004). Member of the Polish Academy of Sciences (since 1983), honorary member of the Polish Psychological Association (since 1984) and the Polish Social Psychology Association. The scientific interests of prof. Janusz Reykowski concern the regulatory role of personality in human life and this thematic scope concerned the consultation of MIAM aviation psychologists.

Mieczysław Choynowski - an outstanding psychologist and consultant in the field of psychometrics at MIAM in the 1970s. Philosopher, founder and head of the Psychometric Workshop of the Polish Academy of Sciences (1959-1969). He studied at the Warsaw University and Jagiellonian University. After the war, he edited the magazine "Życie Nauki" for a short period of time in Cracow. In the 1970s, he emigrated to Sweden and then to Mexico. He lectured at the Universidad

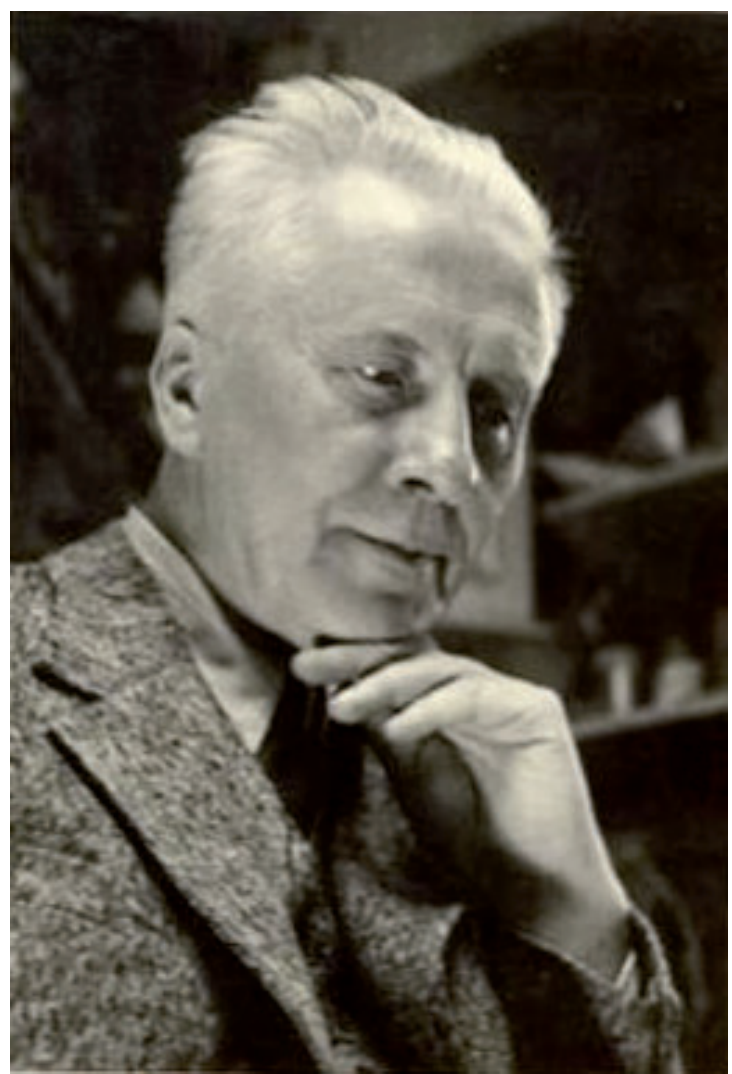

Fig. 9. Mieczysław Choynowski ( 1909-2001), http:// marszalkowska.eu/2013-01-25-nieznaneprace-choynowskiego-w-kwadrydze (12.10.2017).
Pedagógica Nacional in Mexico. In 1963, he developed a memory scale, the so-called Choynowski's memory scale. In 1950-1956 he established and conducted the first modern psychological laboratory in the psychiatric hospital in Kobierzyn near Cracow, which very quickly became a centre of psychodiagnostics methods. In 1956-1970 he organized and conducted the Psychometrical Laboratory of Polish Academy of Sciences in Warsaw. This Laboratory played a very important role in Polish psychological milieu. It built bridges between Polish and western psychologists and between Polish and Central Europe psychologists, independently of political divisions. Thanks to the consultative cooperation of dr. Mieczysław Choynowski, with WIML aviation psychologists and granting access to 20 volumes of Guilford psychometric tests, among which there were several volumes concerning the mental abilities of pilots ${ }^{2}$, it was possible to adapt several dozen of "paperpencil" tests to the examination of several generations of candidates for aviation, included in the socalled "Aviation Tasks". Moreover, dr. Mieczysław Choynowski, before leaving for Mexico, gave Jan Terelak a statistical program (perforated tape for the "Odra" computer, which MIAM had at their disposal at that time), thanks to which the first factor analysis of the structure of temperament in Polish psychology was carried out, using the method of Varimax Kaiser's [34,58] Main Components.

Dr. Mieczysław Choynowski spent his last thirty years in Mexico City engaged in the development of scientific psychology in Mexico. He died in Mexico at the age of 92 , honored by highest scientific awards by Mexican authorities.

Mariusz Maruszewski - psychologist, neuropsychologist, initiator of neuropsychological research in Poland. Consultant at the Military Institute of Aviation Medicine for a very short period in the seventies due to a deadly disease. He studied psychology at the Faculty of Philosophy of the Moscow University in the years 1950-1955. After completing the studies, an assistant at the Chair of General Psychology at the Faculty of Pedagogy of the University of Warsaw. In the years 19581959, he completed an internship at the Institute of Neurosurgery under the direction of Aleksander Łurija. PhD degree in 1960 under the supervi-

2 It should be recalled that just before the US started war operations in Europe, Guilford, as a military psychologist, had been appointed the head of a large team of psychometers to construct a battery of psychological tests useful for carrying out a 'quick' selection of military pilot candidates based on his factorial theory of intelligence. For carrying out that task, Guilford received the rank of a general. 


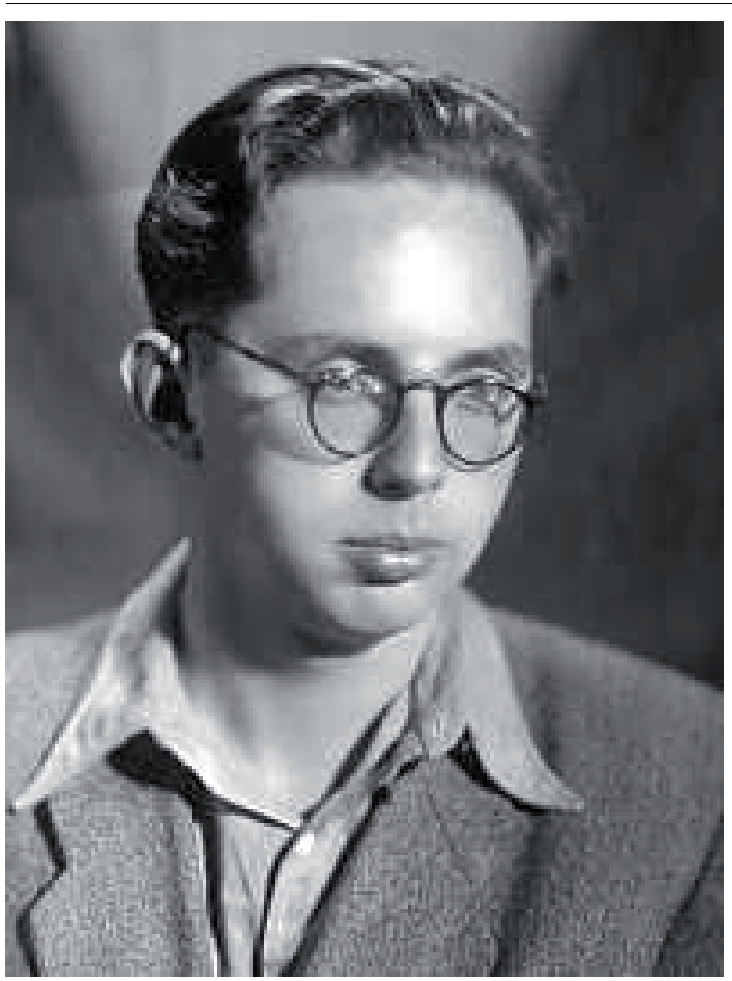

Fig. 10. Mariusz Maruszewski (1932-1973), http:// psych.uw.edu.pl/o-nas/historia/slawniprofesorowiezasluzeni-pracownicy/mariuszmaruszewski/ (12.10.2017).

sion of prof. Tadeusz Tomaszewski. Pioneer in Poland in research on brain mechanisms of speech function and its disorders. Co-founder and head of the Speech Therapy Team at the Department of Neurological Rehabilitation in Konstancin, near Warsaw. Head of the Scientific and Research Team of Neuropsychologists at the University of Warsaw and initiator of the specialization in clinical neuropsychology. He organized the first Clinical Psychology Department in Poland at the Medical University of Warsaw. A number of functions in national and international societies and organizations, including at the Committee on Psychological and Pedagogical Sciences, the U.S. Academy of Aphasia and the Aphasia Research Group at the World Neurology Federation. Main works: "Mowa a mózg" ("Speech and brain") in 1970.

Józef Reutt - Polish psychologist and associate professor at the Catholic University of Lublin and a scientific consultant for aviation psychologists in the 1970s. He studied philosophy at the Stefan Batory University, and then psychology and philosophy at the Sorbonne in France. In 1931, he received his Master's degree at the Vilnius University thanks to his work entitled "Teoria uczuć u Spinozy" ("Spinoza's theory of feelings"), and he defended his PhD thesis entitled "Przedstawienie celu a postępowanie" ("Presentation of pur-

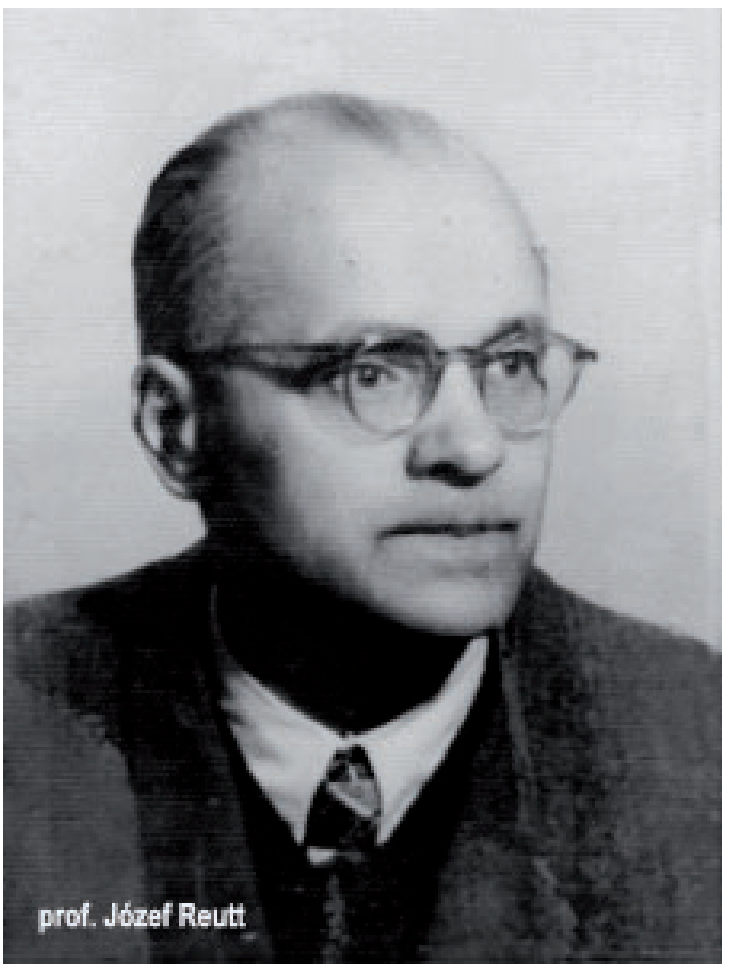

Fig.11. Prof. Józef Reutt (1901-1972), http://www.kul. pl/art_32792.html (12.10.2017).

pose and conduct") during the war at the secret University of Western Lands in Warsaw, and then formally in 1945 at the University of Poznań. He was the secretary of the Polish Psychological Association. In 1951, he began his habilitation at the University of Poznań, but he abandoned it by order of the authorities. Since 1954 he was the head of the Psychological Department Team at the Faculty of Christian Philosophy at the Catholic University of Lublin. In the same year, he was appointed the associate professor of this university. Later, he studied psychophysiological issues based on the Pavlov's work and his methods of teaching. In this respect, he conducted consultations with aviation psychologists, who dealt with the role of temperamental traits in the pilot's activity.

Kazimierz Obuchowski - consultant at the Military Institute of Aviation Medicine for a short period in the seventies - an outstanding specialist in emotional psychology, a professor at the Adam Mickiewicz University in Poznań, a would-be head of the Department of Psychophysiology at MIAM, a reviewer of many scientific works by aviation psychologists. Graduate of psychology at the Adam Mickiewicz University in 1956, an outstanding researcher and academic teacher, creator of fundamental theories in the field of personality psychology, clinical psychology and philosophical 


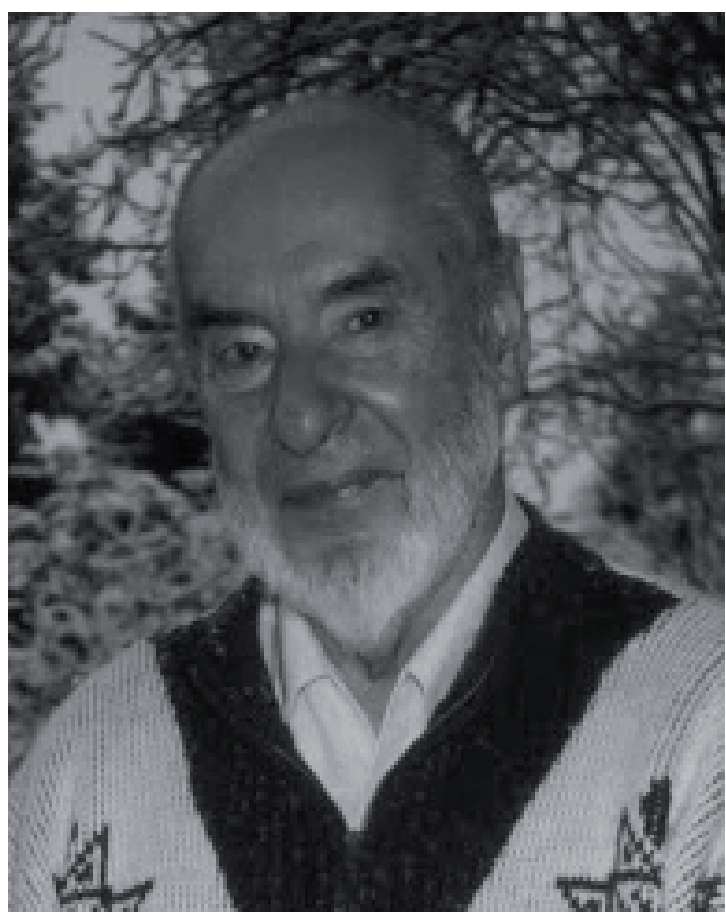

Fig. 12. Prof. Kazimierz Obuchowski (1931-2014), http://uampsych-muzeum.home.amu.edu. pl/kazimierz-obuchowski/ (12.10.2017)

anthropology, an author of monographs important for psychology. He was a long-time employee at the Chief of Clinical Psychology and the Institute of Psychology of the Adam Mickiewicz University, where he headed the Psychological Laboratory of Human Concepts. For many years he was the head of the Department of Personality Psychology at the Institute of Philosophy and Sociology of the Polish Academy of Sciences (a branch in Poznań) and the Institute of Psychology of the Polish Academy of Sciences (a branch in Poznań). He also worked at the Kazimierz Wielki University in Bydgoszcz, where he was the head of the Department of Psychology of Personality. Professor Kazimierz Obuchowski was invited to give lectures at American and European universities.

Jan Strelau - consultant at the Military Institute of Aviation Medicine for a very long period in the eighties and nineties of the twentieth century - a world-famous specialist in the psychology of temperament and intelligence, professor at the University of Warsaw, scientific consultant of the Department of Aviation Psychology for over dozen of years in the seventies and eighties, a promoter of four doctorates in aviation psychology (Janina Maciejczyk, Jan Terelak, Leszek Radomski and Jan Turlejski).

He began his studies at the Catholic University of Lublin, after two years he moved to the University of Warsaw, where he graduated in psy- chology in 1958. From that time until 2001, he remained a research worker at this university, passing through successive stages of his professional career. In 1963, he received his PhD degree. He habilitated in 1968 on the basis of a dissertation entitled "Temperament i typ układu nerwowego" ("Temperament and type of the nervous system"). In 1976, he received the title of a professor of humanities and took the position of an associate professor. In 1982, he became a full professor. In the years 1978-1981 he was the director of the Institute of Psychology. He was the organizer and later the director (1984-2001) of the first in Poland Chair of Psychology of Individual Differences at the Faculty of Psychology, as well as the founder and the director (1998-2001) of the Interdisciplinary Centre of the Behavioural Genetics.

He was the first President of the European Society for Personal Psychology (1984-1988) and also the president of the International Society for the Psychology of Individual Differences (19931995). He held the positions of Vice-President of the International Union of Psychological Sciences (1996-2000) and Vice-President of the Polish Academy of Sciences (2002-2006). He took up editorial positions in scientific journals, i.e. "Polish Psychological Bulletin", "European Psychologist". He was a secretary general and a member of the presidium of the board of the Polish Psychological Association. He is a member of the European Academy of Sciences (Academia Eu-

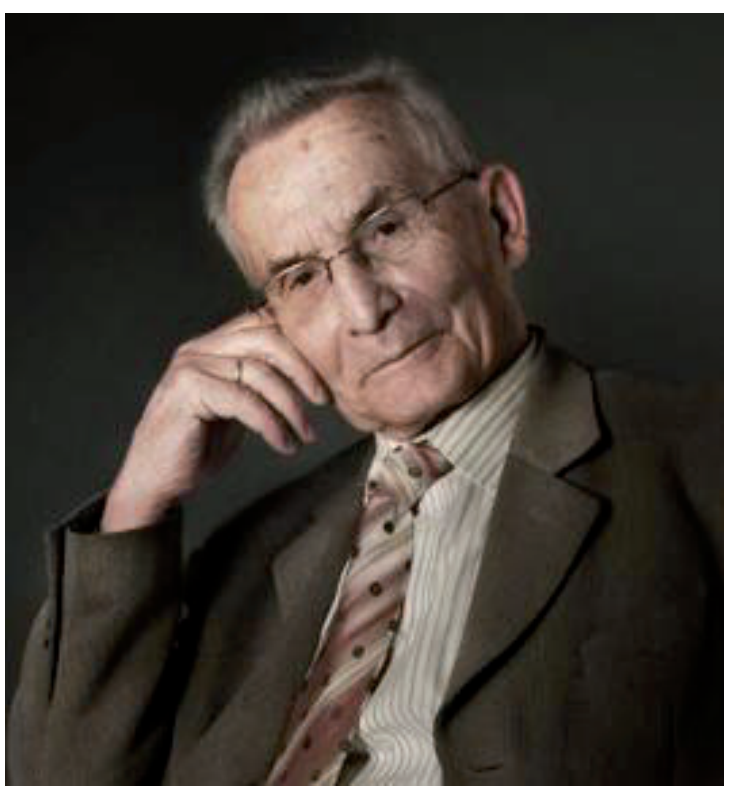

Fig. 13. Prof. Jan Strelau (1931-), http://bw.swps.edu. pl/info/author/IMPORT-PERSON-00002519/ Jan+Strelau;jsessionid=E4C39046D3907A7E 573F0058A91453F4?lang=en\&r=publication $\& t a b=$ publications\&cid=66392 (12.10.2017). 
ropaea), a regular member of the Polish Academy of Sciences and a foreign member of the Finnish Academy of Sciences and Literature. In 2001, he moved to the University of Social Sciences and Humanities, where he became the first dean of the Department of Psychology. In 2002, he took the position of Vice-Chancellor for Science and International Cooperation, and in 2010, of Vice-Chancellor for Science, which he held until 2012. Then he became the President of the Board of Trustee at this university.

Jan F. Terelak (1942-) - scientific consultant at MIAM in the years 2008-2018. He was a longterm employee at WIML at the Department of Psychophysiology and later at the Department

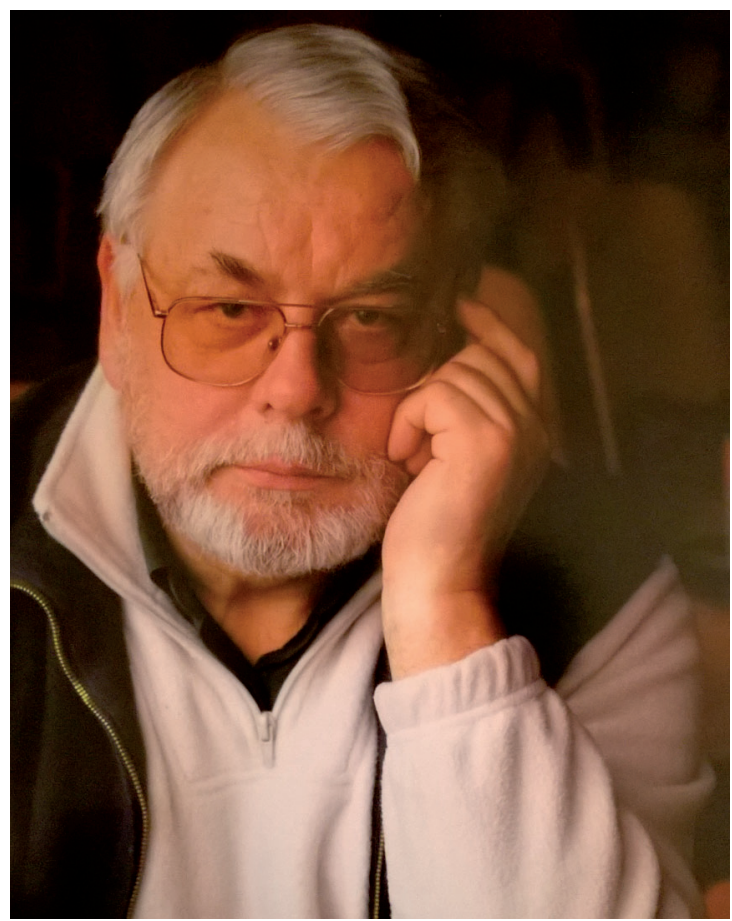

Fig. 14. Prof. Jan F. Terelak (1942-), http://www.wiml. waw.pl/?q=pl/Trzy_sztuki_na_AntarktyceTerelak (12.10.2017). of Aviation Psychology, holding all the positions from assistant to professor and department manager, and after retirement he was a scientific consultant. He specializes in the following issues: clinical psychology, methodology of psychological research, stress psychology, aviation and space psychology. He provided consulting services in this field in the last years of his work at MIAM. At that time he was also the editor-inchief of the scientific journal "The Polish Journal of Aviation Medicine and Psychology". More detailed CV can be found in the article presenting all aviation psychologists from the years 19282018.

\section{CHRONOLOGICAL LIST OF POLISH AVIATION PSYCHOLOGISTS IN THE YEARS 1928-2018}

Within the 90 years of the existence of Military Institute of Aviation Medicine, the following names of aviation psychologists should be listed chronologically: dr. Włodzimierz Missiuro, prof. dr. Bohdan Zawadzki, dr. Piotr Macewicz, dr. Knappe, Elżbieta Dębicka, MA, - dr. Stanisław Trębaczkiewicz, Ewa Walewska, MA, Jan Trojanowski, MA, dr. Krystyna Galubińska, Jolanta Walicka, MA, dr. Romuald Błoszczyński, dr. Janina Maciejczyk, dr. Zbigniew Baranowski, dr. Henryk Świątek (pilot), dr. Piotr Pokinko, Andrzej Eliasz, MA, prof. Jan F. Terelak, dr. Leszek Radomski, dr. Kazimierz Migdał, dr. Zdzisław Kobos, dr. Julian Wonicki, dr. Jan Turlejski, dr. Jacek Szczechura, Krystyna Otrocka, MA, dr. Olaf Truszczyński, dr. Tadeusz Jasiński, Tadeusz Sojka, MA, dr. Adam Tarnowski, Lucyna Jaworska, MA, Marta Szlakowska, MA, Alicja Nakonieczna, MA, Mariusz Turek, MA, dr. Marian Macander, dr. Piotr Zieliński, dr. Marcin Biernacki, Magda Bicka-Capała, MA, Marta Górska, MA, Katarzyna Łapkiewicz, MA, Michał Janewicz, MA, dr. Paulina Baran.

\section{TECHNICAL ASSISTANCE}

Wiesława Domańska (Strupińska), Janina Szymańska, Ewa Opałka, Teresa Ochalska.

\section{AUTHORS' DECLARATION:}

Study Design: Jan F. Terelak; Data Collection: Jan F. Terelak; Manuscript Preparation: Jan F. Terelak. The Author declares that there is no conflict of interest. 


\section{REFERENCES}

1. Błoszczyński R. Badania nad wpływem naziemnego katapultowania z przyspieszeniem $10 \mathrm{G}$ na funkcje psychomotoryczne pilota. Med. Lotn. 1970; 29:73-87.

2. Domaszuk J, Terelak J. Zależności między tolerancją przyspieszeń a stanem emocjonalnym pilotów. Med. Lotn. 1982; 75(2):17-20.

3. Izdebski P. Bronisław Biegeleisen-Żelazowski jako pionier psychologii przemysłowej w Polsce. W: H. Lück, W. Zeidler (red.), Psychologia europejska w okresie międzywojennym. Sylwetki, osiągnięcia, problemy. Warszawa: VIZJA PRESS \& IT. 2011; 235-244.

4. Kwarecki K, Święcicki W, Kłossowski M, Terelak J, Zużewicz K. Zdolność do pracy fizycznej i umysłowej w warunkach 24-godzinnej bezsenności oraz pracy zmianowej. Med. Lotn. 1982; 74(1):7-14.

5. Kwarecki K, Terelak J. Problems of human biology in polish polar research. Postępy Astronautyki. 1981; 14(3):35-49.

6. Łomow BF, Płatonow KK. (red.) Eksperymentalna psychologia lotnicza (Eksperimentalno-psichologiczeskije issledowania w awiacji i kosmonawtikie, Iztwo „Nauka”, Moskwa 1978). Przekład z j. rosyjskiego J. Terelak. Warszawa: PWN, 1984.

7. Maciejczyk J, Kuzak W, Skibniewski FW. Ocena zależności między wybranymi testami psychologicznymi i efektywnościa ćwiczeń na symulatorze lotu. Polski Przegląd Medycyny Lotniczej. 1996; 2(2):137-144.

8. Maciejczyk J, Terelak J. Bibliografia prac z zakresu psychologii lotniczej opublikowana w czasopismach niepsychologicznych w latach 1958-1974. Psychologia Wychowawcza. 1975; 3:458-462;

9. Maciejczyk J, Terelak J. Struktura osobowości pilotów z chorobą wrzodową. Biuletyn WAM. 1986; 29(3):251-255.

10. Maciejczyk J, Terelak J. The psychological manifestations of "Microwave neurosis". Polish Psychological Bulletin. 1978; 9(3):157-162.

11. Markiewicz L. Włodzimierz Jan Missiuro 1892-1967. Acta Physiologica Polonica. 1987; 38(3):255-263.

12. Marks E, Święcicki W, Terelak J. Wpływ jednorazowej dawki acetaminophenu na podzielność uwagi u pilotów. Postępy Astronautyki. 1989; 22(1-2):63-67.

13. Missiuro WJ. Znużenie: 0 fizjologicznych podstawach racjonalizacji pracy. 1947.

14. Pokinko P, Terelak J, Stendera J, Kurzyński J. Urządzenie techniczne do grupowych badań psychologicznych, Przegląd Psychologiczny. 1975; 18(4):567-578;

15. Sokołowski E, Terelak J. Wpływ oddychania mieszaniną helowo-tlenową na koszt fizjologiczny i sprawność umysłową podczas wysiłku fizycznego w podwyższonej temperaturze otoczenia. Ergonomia. 1988; 11:9-15.

16. Szczechura J, Terelak J, Kobos Z, Pińkowski J. Occulographic assessment of workload influence on flight performance. International Journal of Aviation Psychology. 1998; 8(2):157-176;

17. Szczechura J, Terelak J. Charakterystyka wybranych parametrów fiksacji wzroku w działaniu pilota. Przegl. Psychol. 1981; 24(4):103-109.

18. Tarnowski A, Terelak J, Truszczyński O. Special training influences on postural body control of pilot's candidates. In: Proceedings of the 33rd International Applied Military Psychology Symposium, May 12-16 1997, Vienna (Austria).

19. Tarnowski A, Terelak J. Okoruchowy mechanizm uwagi w sytuacji decyzyjnej. Czasopismo Psychologiczne. 1996; 2(3):189-194.

20. Terelak J, Błoszczyński R, Kurzyński J, Stendera J. Urządzenie do automatycznej ekspozycji testów wzrokowych. Przegląd Psychologiczny. 1977; 20(3):547-551.

21. Terelak J, Cieciura M, Terelak H. Warszawski System Testów Psychologicznych „Psychkomp”: Założenia psychologiczne i informatyczne. Przegląd Psychologiczny. 1991; 34(4):647-657.

22. Terelak J, Kobos Z. The formation of eye-hand co-ordination under the influence of exercise on special aviation gymnastic devices. In: Proceedings of the 32nd International Applied Psychology Symposium, May 20-24 1996, Brussels (Belgium).

23. Terelak J, Koter, Z. Wpływ jednorazowego podania etanolu na sprawność umysłową i psychomotoryczną. Psychiatr. Pol. 1986; 20(1):33-37.

24. Terelak J, Kowalski W. Wpływ umiarkowanego stresu termicznego na koszt fizjologiczny oraz sprawność umysłową i psychomotoryczną. Ergonomia. 1991; 14(2):181-192.

25. Terelak J, Sarol Z, Sulajnis H. Ocena warunków podnoszenia kondycji psychofizycznej personelu latającego w WOSK (badania ankietowe). Med. Lotn. 1976; 52:29-35.

26. Terelak J, Szczechura J. Systemowa koncepcja badania wypadków i katastrof lotniczych oraz jej implikacje praktyczne. Prace Komisji Naukowych PAN (Oddział w Katowicach). 1984; 8:104-106.

27. Terelak J, Szczechura J. Zastosowanie badań okulograficznych w locie do oceny ergonomicznej kabiny śmigłowca MI-2. Ergonomia. 1987; 10(1):33-38.

28. Terelak J, Tarnowski A, Dobrowolski A. Kwestionariusz chronotypu człowieka. J.A. Horne i O. Óstberga jako narzędzie badania typów rannych-wieczornych. Przegląd Psychologiczny. 1993; 36(3):363-378.

29. Terelak J, Wojtkowiak M, Klukowski K. Psychologiczne i medyczne uwarunkowania bezpiecznego wykonywania lotów. Informator Instytutu Technicznego Wojsk Lotniczych. 1997; 344:29-43. 
30. Terelak J. Alpha index and personality traits of pilot. Aviat. Space Environ Med. 1976; 47(2):133-136.

31. Terelak J. Artykuły z zakresu psychologii lotniczej opublikowane w czasopismach polskich w latach 1975-1976. Psychologia Wychowawcza. 1978; 4:451-452.

32. Terelak J. Chronopsychologiczna koncepcja źródeł stresu, W: J.F. Terelak (red.), Źródła stresu: Teoria i badania. Warszawa: Wyd. ATK. 1999; 42-69.

33. Terelak J. Current research and trends in Aviation Psychology in Poland. Aviat. Space Environ. Med. 1991; 62(9):903-908.

34. Terelak J. Czynnikowa struktura temperamentu pilotów z różnym poziomem reaktywności. Med. Lotn. 1975; 47:27-37.

35. Terelak J. Emocjonalno-motywacyjne czynniki dezadaptacji lotniczej. Informacja Lotniczo-Lekarska WIML. 1976; 28:60-68.

36. Terelak J. Higiena psychiczna i pilot. Warszawa: Wyd. MON, 1975.

37. Terelak J. Indywidualna odporność pilota na stres psychologiczny, Przegląd WL i WOPK. 1976; 1:27-33.

38. Terelak J. Komputerowe wspomaganie badań psychologicznych na przykładzie struktury Laboratorium Eksperymentalnej Psychologii Lotniczej w Zakładzie Psychofizjologii WIML. Przegląd Psychologiczny. 1994; 37(4):513-524.

39. Terelak J. Krajowa konferencja „Zastosowanie mikrokomputerów w psychologii i pedagogice”, Warszawa 1986. Ergonomia. 1989; 12(1):161-163.

40. Terelak J. Military psychology programs in Poland. Proceedings of the 31th International Applied Military Psychology Symposium, May 15-19.1995, Lisbona, (Portugal), 262- 26.

41. Terelak J. Podstawy psychologii lotniczej. Poznań: DWL, 1988.

42. Terelak J. Przygotowanie i trening naziemny kosmonautów. Astronautyka. 1983; 129(5):8-11.

43. Terelak J. Psychologia lotnicza, W: W. Kowalski (red.) Medycyna lotnicza. Wybrane zagadnienia. Warszawa: Wyd. Fundacja DOCEO. 2001; 313-355.

44. Terelak J. Trends in Poland in Space Psychology Research, Aviation, Space and Environmental Medicine. 1989; 60(4):352-360.

45. Terelak JF. Człowiek w Kosmosie: Bariery adaptacyjne z perspektywy astronautycznej. Studia Philosophiae Christianae. 2016; 52(3):111-129.

46. Terelak JF. Człowiek w sytuacjach ekstremalnych. Izolacja antarktyczna. Warszawa: Wyd. MON, 1982.

47. Terelak JF. Introspekcje antarktyczne. Diariusz psychologa polarnego. Warszawa: Wyd. MON, 1982.

48. Terelak JF. The emergence and development of space psychology in Poland: The significance of historical space flight of Mirosław Hermaszewski. Polish Journal of Aviation Medicine and Psychology. 2013; 19(3):23-36.

49. Terelak JF. Udział psychologii lotniczej w 80-letniej działalności naukowo-badawczej WIML z perspektywy 40 lat pracy. Polski Przegląd Medycyny Lotniczej. 2008; 2(14):135-150.

50. The 25th Jubilee European Association for Aviation Psychology Conference: Safety, Systems and Peaple in Aviation, 16-20th 2002, Warsaw (Poland), (paper: Smolicz T, Terelak JF. The new face of terrorism).

51. The 34th International Applied Military Psychology Symposium, Paris (France), 25-29 May 1998, (paper: Truszczyński 0, Terelak JF. Military psychology in Poland and its future transformation).

52. The 35th International Applied Military Psychology Symposium, Firenze (Italy), 24-28 May 1999, (paper: Truszczyński 0, Terelak JF. The adjustment of Polish Aviation Psychology to NATO standards).

53. The 39th Annual Conference International Military Testing Association, Sydney (Australia), 14-16 October 1997, (referat: Tarnowski A, Terelak J. Vienna Test System based battery for selection Polish Air Force pilots).

54. The 39th Annual Conference International Military Testing Association, Sydney (Australia), 14-16 October 1997, (paper: Truszczyński O, Terelak J, Tarnowski A. Saccadic latencies as a indicator of attention processes under altitude hypoxia).

55. The 41st Annual Conference of the International Military Testing Association (IMTA) and NATO Reaserch and Technology Organization Human Factors and Medicine Panel Workshop, November 9-11, 1999, Monterey (California, USA), (referat: Truszczynski O, Terelak J. The Conceptual Systems of the Primary Psychological Selection of Officer Applicants to Military High Schools from Air Force, Navy and Army in Poland).

56. The 7th International Symposium on Aviation Psychology, Columbus (Ohio, USA), 26-29.04.1993, (paper: Terelak J. Anxiety and eye-hand-legs coordination in young pilots).

57. Truszczyński O, Terelak JF, Turek M. Personality of Polish Soldiers and their way stress-coping during Bosnia Peacekeeping Mission, In: Proceedings of the 36th International Applied Military Psychology Symposium (IAMPS) at Split (Croatia), 11-15 September 2000, Changing mission for the 21st century, Zagreb 2000; 251-256.

58. Zużewicz K, Terelak J. Zastosowanie analizy czynnikowej w badaniach medyczno-psychologicznych personelu latającego. Med. Lotn. 1977; 57:23-30.

Cite this article as: Terelak J.F. Characteristics of The Scientific and Implementational Activities of Aviation Psychologists and Scientific Consultancy from The Perspetive of The 90 Years of Existence of The Military Institute of Aviation Medicine. Pol J Aviat Med Bioeng Psychol 2017; 23(3-4): 74-87. DOI: 10.13174/pjambp.20.12.2018.11 